\title{
Study and Analysis of Routing Protocols
}

\author{
P. Srikanth Reddy, P. Saleem Akram, M. Adarsh Sharma, P. Aditya Sai Ram, R. Pruthvi Raj \\ saleemakramp@gmail.com, adarshsharmamadiraju@gmail.com, ravi.pasam23@gmail.com, pruthvirajrayudu@gmail.com \\ Department of Electronics and communication Engineering \\ Koneru Lakshmaiah Education Foundation \\ Vaddeswaram, Guntur dist. Andhra Pradesh, India
}

\begin{abstract}
In the past few years, modern topologies has changed drastically because of the development of new forms in the routing protocols. In this modern age, the plan process will come into existing services and those can be achieved in upcoming days bearing in mind that we are currently watching an impressive growth of the congestion created by the different applications. It is mainly focused on the relative analysis using the Cisco Packet Tracer of the routing Open Shortest Path First (OSPF), Enhanced Interior Door Routing Protocol (EIGRP), Routing Information Protocol (RIPv2).
\end{abstract}

Key words: HTTPS, RIP, Cisco Packet Tracer, routing protocols, DNS, HTTP

\section{INTRODUCTION}

When the first computers were developed, the importance of interconnection led the foremost interest in sharing the results obtained after performing different tasks for which they were initially programmed. Some of the manufacturers started to develop their own interconnection in frameworks [1] for their computer as time passed. Although the need of interlinkage became a foremost issue between users, because of the different protocols which we use in different topographical areas intercommunication became tougher.

The first small actual networks emerged alongside when we found solution to the first issue, which are known as Local Area Network (LAN). In the second level Metropolitan area network (MAN) networks, was developed along with the PC's and different devices (mobile Mobile Phones communication with the help of IP, printers, remaining smart devices with which we can communicate). The Wide Area networks (WAN) are not topographically limited relative to MAN networks. Interconnection is the main advantage in LAN. The price was actually more expensive, because of high speed networks in LAN.

The computer networks now provide us with the opportunity to communicate in actual time. We use networks for maximum ability because we want networks to use in maximum applications such as:

Online applications, File Transfer Protocol (FTP), Terminal Emulation (TELNET), and Email Programs, Groupware.

\section{BRIEF INTRODUCTION ABOUT INTERNET PROTOCOLS (IP):}

Keeping in mind about the preferences of the network administrator, the routing protocols must be well developed and configured for every network. These are

Auto Adaptive because they converge very quickly stands as big advantage for routing protocols.

If the performance of the hardware is not up to the mark we should carefully choose the approach or solution for the improvement of routing protocol.

There are two dynamic levels of routing protocols. They are [2-4]

1. Interior routing protocols

2. Exterior routing protocols

\section{a. Level 1 Routing Protocol - Interior}

Protocols for interior routing are defined as follows:

1. Link State Protocols

2. Distance Vector

The following protocols belong to the category "Distance vector": OSPF [5], EIGRP [6] RIPv1 [7] and RIPv2 [9-11] following characteristics describe these protocols:

1. Routing loops is biggest issue.

2. There is no picture explanation of network topology;

3. Hardware is not taxable;

4. Algorithms are very easy to implement and measure by the processor;

5. On small networks, they are scaled

6. We facilitate authentication;

The Open Shortest Path First (OSPF) and Intermediate system and Intermediate system (IS-IS) protocols [12 14] are known as "Link state". The following feature characterizes these protocols:

1. We give more complicated (Dijkstra) algorithms that use knowledge from all network devices. In addition, we rebuild the topology of entire network, assessing the network hardware devices ' processing power taxation. 
2. They determine the shortest route;

3. Advertisement of link state [15] will be created and alerted to entire network, and each router that uses it will measure the complete network routing table and is called as the linkstate database;

4. The downside of the protocol [16] in terms of cost because we need hardware of great performance that can handle the measure the whole topology of the network.

If we have a chance through route from different routing protocols we use the route of the distance which have shorter administrative .OSPF has administrative distance of 120 while administrative distance of EIGRP is 90 . So if we route between these two we use EIGRP because of shorter administrative distance.

The proposed LAN working principle having application as Wireless Sensor nodes [17] by using miniature antennas [18].

ROUTING INFORMATION PROTOCOL (RIP v1). The complete process is based on routing information of hop count. We have a hop limit of 15 hops on packets. If we get value of 16 as hop count the packet will be dropped. It is a classful protocol. We have administrative distance of 120. RIP supports at most six equal paths to a single destination

ROUTING INFORMATION PROTOCOL (RIP v2). - It is a distance vector routing protocol and known as hybrid routing protocol.

It is the advancement version of RIPv1.We has administrative distance of 120 . We use in small networks and also in CIDR. Here we use multicast. It acts as an authentication support with the help of VLSM (VariableLength Subnet Mask)

RIPv1 and RIPv2 use routing information as hop count.

\section{OPEN SHORTEST PATH FIRST (OSPF).}

It is used for secure message transmission. We use Dijkstra algorithm to find the shortest route. We get graph with the help of formula, and allot certain cost between two connecting points. OSPF is developed by Internet Engineering Task Force (IETF) as Interior Gateway Protocol (IGP), i.e., the protocol that aims at moving the packet within a large independent system or routing. It is a network layer protocol which works on protocol number89 and uses administrative distance of 110 . The OSPF protocol uses IP 224.0.0.5 and 224.0.0.6 to communicate via multicast messages.

Enhanced Interior Gateway Routing Protocol (EIGRP). It was introduced in the mid-eighties by Cisco as a competitor with OSPF, because of its flexible algorithm which is very easy, it can even work well on big size networks but this is not in the case of OSPF. Up to 2015, this
One was only used on Cisco devices. Since 2015, it was available for free use and now EIGRP is most efficient of all.

Table I: Comparison between Routing Protocols

\begin{tabular}{|l|l|l|l|}
\hline Protocol & RIP & OSPF & EIGRP \\
\hline $\begin{array}{l}\text { Time } \\
\text { of Convergence }\end{array}$ & - & + & + \\
\hline Patented & x & x & $\checkmark$ \\
\hline $\begin{array}{l}\text { Usage of } \\
\text { Bandwidth }\end{array}$ & $\uparrow$ & $\downarrow$ & \\
\hline $\begin{array}{l}\text { Usage of } \\
\text { Resource }\end{array}$ & $\downarrow$ & $\uparrow$ & $\uparrow$ \\
\hline $\begin{array}{l}\text { Supporting } \\
\text { Multiple } \\
\text { path }\end{array}$ & $x$ & $\checkmark$ & \\
\hline Non-IP protocol & $\mathbf{x}$ & $\mathbf{x}$ & $\checkmark$ \\
\hline VLSM & $\mathbf{x}$ & $\checkmark$ & $\checkmark$ \\
\hline Scalability & $\mathbf{r}$ & $\checkmark$ \\
\hline
\end{tabular}

Table1: In this table (-) represents Slow and (+) represents High; ( $\uparrow)$ represents High and $(\downarrow)$ represents low; (x) represents no and $(\checkmark)$ represents yes ;

\section{b. Level 2 Protocols - Exterior}

It has just one sort -"Path Vector Routing Protocol". To this sort have a place the accompanying protocols: Border Gateway Protocol (BGP) and Exterior Gateway Protocol (EGP). These are typically utilized for connecting internet services and enormous organizations. They are particularly made and utilized for web.

\section{RELATIVE STUDY OF THE ROUTING IN CISCO PACKET TRACER}

It is a Software developed by Cisco organization so as to simulate devices (router 2811, switch 2960, Voice Over Internet Protocols 7960 cell Mobile Phones, computers and other devices that can be allocated to IP-s) and different protocols used for interconnecting devices to build networks; they canbe contemplated with regard to their purpose in order to avoid problems that may arise.

By using the software, we created and analysed computer network which we have classified into six departments. At first the admin block we designed multiple workstations (workplace 1, 2, 3, 4, 5, 6, 7, 8, 9 - students of admin block, Server3, admin block) which will route IPs from router 2 by Dynamic Host Configuration Protocol (DHCP) from network 10.20.30.0/22, server3 admin block and a wireless router that allocates IPs in 192.169.0.0/26 using the similar technique. We use $3 \mathrm{G}$ connection for cell Mobile Phones and tablet are interconnected to network of 192.168.1.5/29 (Figure 1). We gave Virtual Local Area Network (VLAN) names as Electronic students, Electrical Students, Mechanical Students, Computer students. 


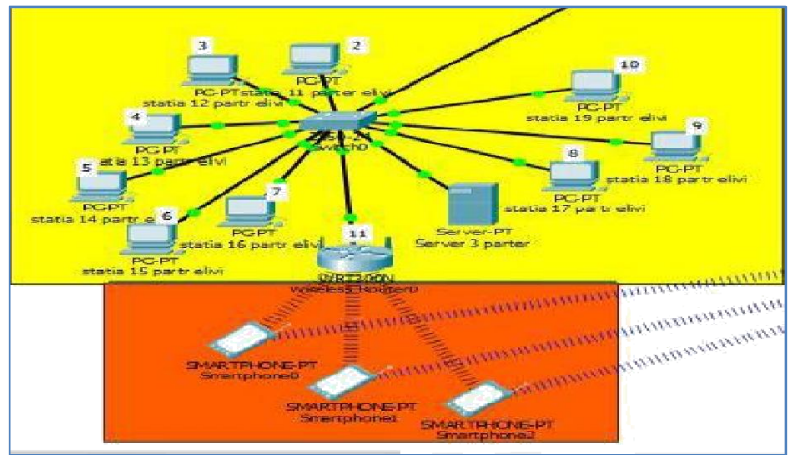

Figure 1: Admin block area of the applications

We built 4 VLANs and gave names for Management block as: Electronic students, Electrical Students, Mechanical Students, Computer students. The following networks have been defined by the VLAN: Electronic students-192.0.1.0/24, Electrical Students -192.0.2.0/24, Mechanical Students -192.0.3.0/24 and Computer students-192.0.99.0/24 (Figure 2).

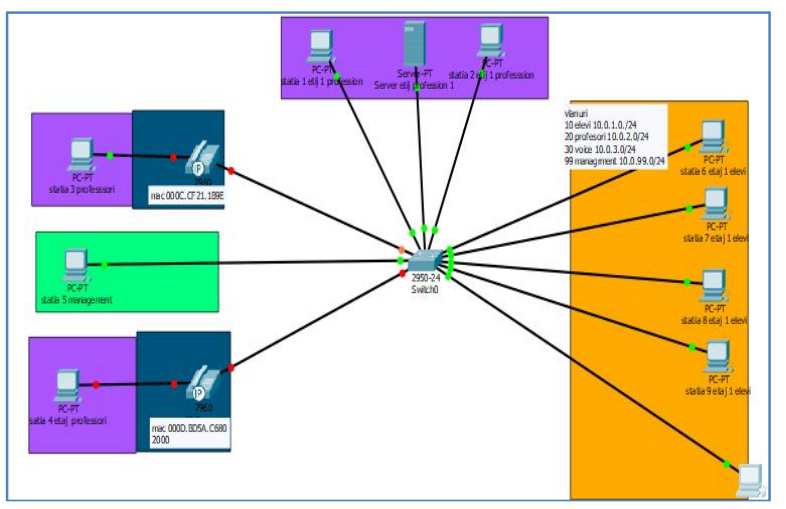

Figure 2: Management block Area

In Admission block, We built 4 VLANs and gave names as: :Electronic students, Electrical Students, Mechanical Students, Computer students and the following networks were allocated to: Electronic students -192.1.1.0/24, Electrical Students -192.1.2.0/24, Mechanical Students 192.1.3.0/24 and Computer students-192.0.99.0/24. All users receive IPs from router 4 using the DHCP protocol (Figure 3).

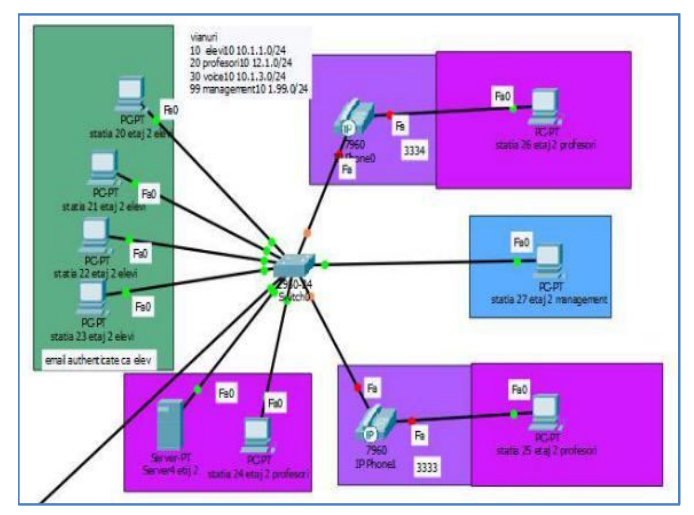

Figure 3: Admission block Area
We built 4 VLANs and gave names for hostel block as: Electronic students-192.3.1.0, Electrical Students 192.3.2.0, Mechanical Students -192.3.2.0 and Computer students-192.0.99.0. In addition to the workstations, in this area we also consider a web server with a static IP 192.3.2.2/24 declared on DNSserver so that any computer from any network can access the site www.cezar.ro (Figure 4).

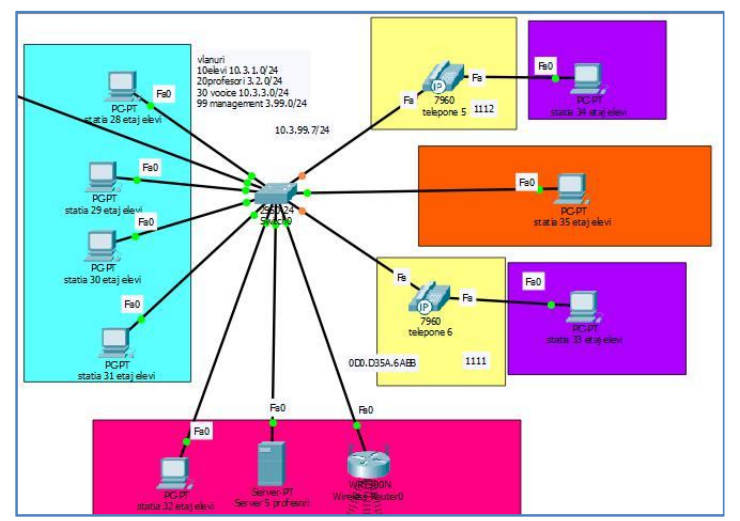

Figure 4: Hostel block area

Home is the fifth area. It is a database that provides access to the devices such as: workshop, camera, study lamp, central heating $(\mathrm{CH})$, (TMD) Temperature monitoring device and air conditioner (AC). Every devices is allocated to 101.217.1.0/24as static IPs. With the help of 3G area and SmartMobile Phone 2 we open workshop door. We're opening the IOE control application to access the Home Administration Server. We use 2202 as password and cezar as user name. Upon establishing the connection, all system parameters can be controlled and modified in this area (Figure 5).

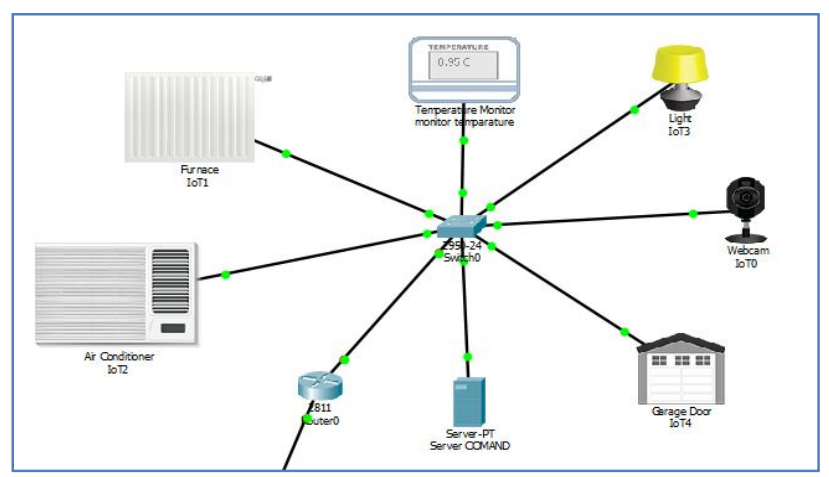

Figure 5.: Waiting Room

Here in the waiting room we can switch on the home appliances such as light, fan, air conditioner etc.., with the help of wireless router by using smart Mobile Phone.

The Servers area which we have created has DOMAIN NAME SYSTEM, ELECTRONIC-MAIL, NETWORK TIME PROTOCOL and CENTRAL OFFICE SERVER 3G 


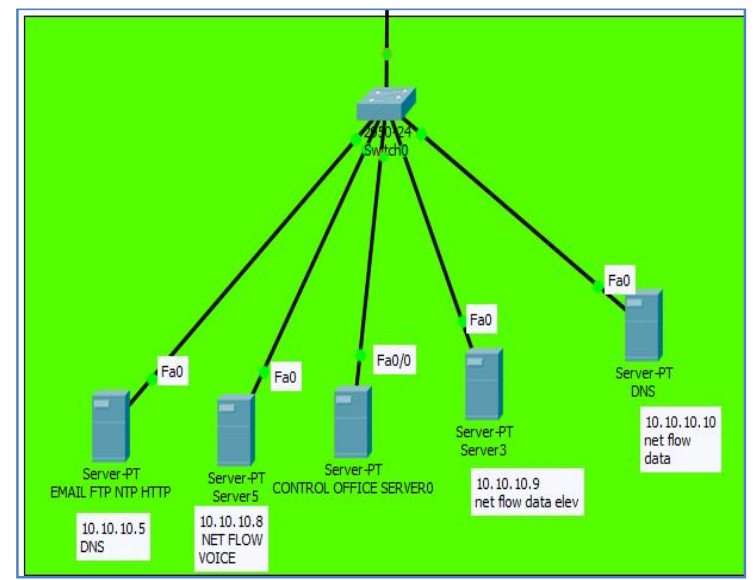

Figure 6: Servers Area

Here we use 4 Smart Mobile Phones in which Smart Mobile Phone 0 and Smart device 1 which have IPs are in contact with wireless router in Admin block and also connected to wireless network.

Remaining Smart devices are in contact with wireless router in Hostel block and not only to router but also to $3 \mathrm{G}$ network. We will also use 2 tablets and they are tablets 0 and tablets 1 and these are also connected in the same pattern as Smart devices are connected and $\mathrm{Wi}-\mathrm{Fi}$ acts as medium for those two routers and basic work station is $3 \mathrm{G}$

\section{A. First Situation - study of network using EIGRP routing protocol}

In this Case we've got designed the routers with the assistance of EIGRP routing protocol

The reaction times obtained for this case are shown in table II and table III

Table 2: REACTION TIMES IN FIRST SITUATION EIGRP PROTOCOL (DNS, HTTPS)

\begin{tabular}{|l|l|l|l|}
\hline The Second Situation - OSPF Protocol \\
\hline Time (s) & DNS Service & Time(s) & $\begin{array}{l}\text { HTTPS } \\
\text { Service }\end{array}$ \\
\hline 0 & Workplace & 0.022 & Workplace \\
\hline 0.002 & $\begin{array}{l}\text { Admin block } \\
\text { Switch }\end{array}$ & 0.023 & $\begin{array}{l}\text { Admin block } \\
\text { Switch }\end{array}$ \\
\hline 0.003 & Router - 2 & 0.024 & Router - 2 \\
\hline 0.004 & Router - 3 & 0.025 & Router - 1 \\
\hline 0.005 & $\begin{array}{l}\text { Servers Room } \\
\text { Switch }\end{array}$ & 0.026 & Router - 4 \\
\hline 0.006 & Server DNS & 0.027 & $\begin{array}{l}\text { Hostel block } \\
\text { Switch }\end{array}$ \\
\hline 0.007 & $\begin{array}{l}\text { Servers Room } \\
\text { Switch }\end{array}$ & 0.028 & $\begin{array}{l}\text { Server } \\
\text { Faculty }\end{array}$ \\
\hline 0.008 & Router - 3 & 0.029 & $\begin{array}{l}\text { Hostel block } \\
\text { Switch }\end{array}$ \\
\hline 0.009 & Router - 2 & 0.030 & Router - 4 \\
\hline 0.010 & $\begin{array}{l}\text { Admin block } \\
\text { Switch }\end{array}$ & 0.031 & Router - 1 \\
\hline 0.011 & Workplace & 0.032 & Router - 2 \\
\hline & & 0.033 & $\begin{array}{l}\text { Admin block } \\
\text { Switch }\end{array}$ \\
\hline & & 0.034 & Workplace \\
\hline
\end{tabular}

Table 3: REACTION TIMES IN FIRST SITUATION EIGRP PROTOCOL (HTTP, RTP)

\begin{tabular}{|l|l|l|l|}
\hline \multicolumn{3}{|l|}{ First Situation-EIGRP Protocol } \\
\hline Time (s) & HTTP Service & Time (s) & RTP Service \\
\hline 0 & $\begin{array}{l}\text { Smart device - } \\
2\end{array}$ & 0 & Mobile phone - 1 \\
\hline 0.002 & $\begin{array}{l}\text { Wireless router } \\
-0\end{array}$ & 0.002 & $\begin{array}{l}\text { Management } \\
\text { block Switch }\end{array}$ \\
\hline 0.003 & $\begin{array}{l}\text { Hostel block } \\
\text { Switch }\end{array}$ & 0.003 & Router- 2 \\
\hline 0.004 & Router - 4 & 0.004 & Router- 3 \\
\hline 0.005 & Router - 1 & 0.005 & Router- 4 \\
\hline 0.006 & Home Router & 0.006 & $\begin{array}{l}\text { Admission block } \\
\text { Switch }\end{array}$ \\
\hline 0.007 & Home Switch & 0.007 & Mobile phone - 3 \\
\hline 0.008 & $\begin{array}{l}\text { Administration } \\
\text { server }\end{array}$ & & \\
\hline 0.010 & Home switch & & \\
\hline 0.011 & Home Router & & \\
\hline 0.012 & Router - & & \\
\hline 0.013 & Router - 4 & & \\
\hline 0.014 & $\begin{array}{l}\text { Hostel block } \\
\text { Switch }\end{array}$ & & \\
\hline 0.015 & $\begin{array}{l}\text { Wireless router } \\
-0\end{array}$ & & \\
\hline 0.021 & $\begin{array}{l}\text { Smart device - } \\
2\end{array}$ & & \\
\hline
\end{tabular}

Above results in table II \& table III are the results for the EIGRP protocol. From these results we can observe;

- While gaining access to the web server inbetween the workplace, Admin block Students and Server 4 Faculty. If we use the service HTTPS from the starting of the browser and the time taken by the web page is 0.034 sec.

- If we use the HTTP Protocol in the direction of Smart device - 2 to Administration Server and Smart device - 2 we got the delay of $0.021 \mathrm{sec}$.

- If we use the Real Time Transfer Protocol between Mobile phone 1 and Mobile phone 3 we got the delay of $0.007 \mathrm{sec}$.

\section{B. Second Situation - study of network using routing protocol OSPF}

In this Case, The reaction times are given in Table IV and Table V.

Table 4: REACTION TIMES IN CASE OF SECOND SITUATION - OSPF PROTOCOL (DNS, HTTPS)

\begin{tabular}{|l|l|l|l|}
\hline \multicolumn{4}{|l|}{ The Second Situation - OSPF Protocol } \\
\hline Time (s) & DNS Service & Time(s) & HTTPS Service \\
\hline 0 & Workplace & 0.022 & Workplace \\
\hline 0.002 & $\begin{array}{l}\text { Admin block } \\
\text { Switch }\end{array}$ & 0.023 & Admin block Switch \\
\hline 0.003 & Router - 2 & 0.024 & Router - 2 \\
\hline 0.004 & Router - 3 & 0.025 & Router - 1 \\
\hline 0.005 & $\begin{array}{l}\text { Servers Room } \\
\text { Switch }\end{array}$ & 0.026 & Router - 4 \\
\hline 0.006 & Server DNS & 0.027 & Hostel block Switch \\
\hline 0.007 & $\begin{array}{l}\text { Servers Room } \\
\text { Switch }\end{array}$ & 0.028 & Server 4 Faculty \\
\hline 0.008 & Router - 3 & 0.029 & Hostel block Switch \\
\hline 0.009 & Router - 2 & 0.030 & Router - 4 \\
\hline 0.010 & $\begin{array}{l}\text { Admin block } \\
\text { Switch }\end{array}$ & 0.031 & Router - 1 \\
\hline 0.011 & Workplace & 0.032 & Router - 2 \\
\hline & & 0.033 & Admin block Switch \\
\hline & & 0.034 & Workplace \\
\hline
\end{tabular}


P. Srikanth Reddy et al., International Journal of Emerging Trends in Engineering Research, 7(11), November 2019, 434 - 440

Table 5: REACTION TIMES IN CASE OF SECOND SITUATION - OSPF PROTOCOL (HTTP, RTP)

\begin{tabular}{|l|l|l|l|}
\hline \multicolumn{5}{|l|}{ The Second Situation - EIGRP Protocol } \\
\hline Time(s) & HTTP Service & Time(s) & RTP Service \\
\hline 0 & $\begin{array}{l}\text { Smart device- } \\
2\end{array}$ & 0 & Mobile Phone- 1 \\
\hline 0.003 & $\begin{array}{l}\text { Wireless } \\
\text { router - 0 }\end{array}$ & 0.002 & $\begin{array}{l}\text { Management } \\
\text { block Switch }\end{array}$ \\
\hline 0.004 & $\begin{array}{l}\text { Hostel block } \\
\text { Switch }\end{array}$ & 0.003 & Router- 2 \\
\hline 0.005 & Router - 4 & 0.004 & Router- 3 \\
\hline 0.006 & Router - 1 & 0.005 & Router- 4 \\
\hline 0.007 & Home Router & 0.006 & $\begin{array}{l}\text { Management } \\
\text { block Switch }\end{array}$ \\
\hline 0.008 & Home Switch & 0.007 & Mobile Phone- 1 \\
\hline 0.009 & Server - 1 & & \\
\hline 0.011 & Home Switch & & \\
\hline 0.012 & Home Router & & \\
\hline 0.013 & Router - 1 & & \\
\hline 0.014 & Router - 4 & & \\
\hline 0.015 & $\begin{array}{l}\text { Hostel block } \\
\text { Switch }\end{array}$ & & \\
\hline 0.016 & $\begin{array}{l}\text { Wireless } \\
\text { router - 0 }\end{array}$ & & \\
\hline 0.022 & Smart device-2 & & \\
\hline
\end{tabular}

The above Tables; table VI \& table V are the results for the OSPF protocol. From these results we can observe:

- While gaining access to the web server inbetween the workplace Admin block Students and Server 4 Faculty, if we use the HTTPS service from the time of starting of the browser to display the web page the time taken is $0.034 \mathrm{sec}$.

- If we use the HTTP Protocol in the direction of Smart device - 2, Administration Server and Smart device - 2 we got the delay of $0.022 \mathrm{sec}$.

- If we use the Real Time Transfer Protocol between Mobile phone 1 and Mobile phone 3 we got the delay of $0.007 \mathrm{sec}$.

\section{Third Situation - study of network using RIPv2 routing protocol}

In this case, the Reaction times are given in table VI and VII.

Table 6: REACTION TIMES IN CASE OF THIRD SITUATION - RIPV2 PROTOCOL (DNS, HTTPS)

\begin{tabular}{|l|l|l|l|}
\hline The Third Situation - OSPF Protocol \\
\hline Time (s) & DNS Service & Time(s) & $\begin{array}{l}\text { HTTPS } \\
\text { Service }\end{array}$ \\
\hline 0.003 & workplace & 0.330 & Workplace 16 \\
\hline 0.004 & $\begin{array}{l}\text { Admin block } \\
\text { Switch }\end{array}$ & 0.331 & $\begin{array}{l}\text { Admin block } \\
\text { Switch }\end{array}$ \\
\hline 0.005 & Router - 2 & 0.332 & Router - 2 \\
\hline 0.006 & Router - 3 & 0.333 & Router - 1 \\
\hline 0.007 & $\begin{array}{l}\text { Server Room } \\
\text { Switch }\end{array}$ & 0.334 & Router - 4 \\
\hline 0.008 & Server-DNS & 0.335 & $\begin{array}{l}\text { Hostel block } \\
\text { Switch }\end{array}$ \\
\hline 0.009 & $\begin{array}{l}\text { Servers Room } \\
\text { Switch }\end{array}$ & 0.336 & $\begin{array}{l}\text { Server - } \\
\text { Teachers }\end{array}$ \\
\hline 0.010 & Router - 3 & 0.337 & $\begin{array}{l}\text { Hostel block } \\
\text { Switch }\end{array}$ \\
\hline 0.011 & Router - 2 & 0.338 & Router - 4 \\
\hline 0.012 & $\begin{array}{l}\text { Admin block } \\
\text { Switch }\end{array}$ & 0.339 & Router - 3 \\
\hline 0.013 & workplace & 0.340 & Router - 2 \\
\hline & & 0.341 & $\begin{array}{l}\text { Admin block } \\
\text { Switch }\end{array}$ \\
\hline & & 0.342 & workplace \\
\hline
\end{tabular}

Table 7: REACTION TIMES IN CASE OF THIRD SITUATION - RIPV2 PROTOCOL (HTTP, RTP)

\begin{tabular}{|c|c|c|c|}
\hline \multicolumn{4}{|c|}{ The Third Situation - EIGRP Protocol } \\
\hline Time(s) & $\begin{array}{l}\text { HTTP } \\
\text { Server }\end{array}$ & Time(s) & RTP Service \\
\hline 0.004 & $\begin{array}{l}\text { Smart device } \\
-2\end{array}$ & 0.026 & Mobile Phone- 1 \\
\hline 0.005 & $\begin{array}{l}\text { Wireless } \\
\text { router - } 0\end{array}$ & 0.027 & $\begin{array}{l}\text { Management } \\
\text { block Switch }\end{array}$ \\
\hline 0.006 & $\begin{array}{l}\text { Hostel block } \\
\text { Switch }\end{array}$ & 0.028 & Router- 2 \\
\hline 0.007 & Router - 4 & 0.029 & Router- 3 \\
\hline 0.008 & Router - 1 & 0.030 & Router- 4 \\
\hline 0.009 & Home Router & 0.031 & $\begin{array}{l}\text { Admission block } \\
\text { Switch }\end{array}$ \\
\hline 0.010 & Home Switch & 0.032 & Mobile Phone- 3 \\
\hline 0.011 & Server - 1 & & \\
\hline 0.013 & Home Switch & & \\
\hline 0.014 & Home Router & & \\
\hline 0.015 & Router - 1 & & \\
\hline 0.016 & Router - 4 & & \\
\hline 0.017 & $\begin{array}{l}\text { Hostel block } \\
\text { Switch }\end{array}$ & & \\
\hline 0.018 & $\begin{array}{l}\text { Router- } \\
\text { Wireless - } 0\end{array}$ & & \\
\hline 0.023 & $\begin{array}{l}\text { Smart device } \\
-2\end{array}$ & & \\
\hline
\end{tabular}

From the above results in table VI and table VII in the case of RIPv2 protocol, we observe:

- While gaining access to the web server inbetween the workplace Admin block Students and Server 4 Faculty, If we use the HTTPS service from the time of starting of the browser and the time of display of the web page the time taken was $0.33 \mathrm{sec}$;

- If we use the HTTP Protocol in the direction of Smart device - 2, Administration Server and Smart device - 2, we got the delay of $0.023 \mathrm{sec}$;

- If we use the Real Time Transfer Protocol between Mobile Phone 1 to Mobile Phone 3 we got the delay of 0.032 s.

\section{CONCLUSION}

From the Simulation and their outputs, wecome to a conclusion that the EIGRP Protocol is more efficient because of its algorithm which is not complicated unlike that of the OSPF; We can scale EIGRP protocol in not only medium networks but also in large networks, whereas the OSPF is very well covered on medium and large networks, afterwards it will find the short route. Every router will send the routing table to the entire network and the router which is using this routing table will calculate the topology of whole network, needs huge resources and cost is higher than that of the EIGRP. Another routing protocol is the RIP protocol as it has bad timing it generates delays in the network.

From the response time we can distinguish the routing protocols and these differences are because of the algorithms which produce delays. One of the capable software for the simulation is the CISCO PACKET TRACER which helps to design and simulates the virtual networks. This helps us to find the less traffic congestion route and also helps in increasing the network security. 


\section{REFERENCES}

[1] Ravi Malhotra, IP routing, O'Reilly Media, 2002.

[2] L.D. Circiumarescu, G. Predusca, N. Angelescu, D. Puchianu, "Comparative analysis of protocol RIP, OSPF, EIGRP and IGRP for service Video conferencing, E-mail, FTP, HTTP", CSC20, CSCS20, The 20th International Conference on Control Systems and Computer Science 27-29 May 2015, Faculty of Automatic Control and Computers, University Politehnica of Bucharest, Romania, pp.584-589. https://doi.org/10.1109/CSCS.2015.17

[3] Uyless Black, IP routing protocols: RIP, OSPF, BGP, PNNI and Cisco routing protocols, Prentice Hall Professional, New Jersey, USA, 2000.

[4] Ioan Fitigau, Gavril Toderean, "Network performance evaluation for RIP, OSPF and EIGRP routing protocols," International Conference on Electronics, Computers and Artificial Intelligence (ECAI), 27-29 June 2013, pp.1-4. https://doi.org/10.1109/ECAI.2013.6636217

[5] Eduard Tetz, Cisco networking all-in-one for dummies, John Wiley \& Sons Ltd, 2011.

[6] Megha Jayakumar, N. Ramya Shanti Rekha, B. Bharathi, "A comparative study on RIP and OSPF protocols," International Conference on Innovation in Information, Embedded and Communication Systems (ICIIECS), 1920 March 2015, pp.1.5 .

[7] Jesin A, Packet Tracer Network Simulator, Packet Publishing, 2014.

[8] Zhu Dawei, Yuan Jing, Chen Rui, Yang Jie, Han Xinyu, "The Implementation of Routing Information Protocol Porting to the Switching System", 2015 Seventh International Conference on Measuring Technology and Mechatronics Automation. https://doi.org/10.1109/ICMTMA.2015.297

[9] W.V. Wollman; Y. Barsoum, "Overview of open shortest path first, version 2 (OSPF V2) routing in the tactical environment", Published in:Proceedings of MILCOM '95, 5-8 Nov. 1995.

[10] Kayvan Atefi: Amir Hossein Shahin; Saadiah Yahya; Alireza Erfanian,'Performance evaluation of 802.3u standard". Published in: $20163^{\text {rd }}$ International Conference on Computer and Information Sciences (ICCONIS),15-17 Aug. 2016, Kualalampur, Malaysia.

[11] Y.Navaneeth Krishnan : G Shobha, "Performance analysis of OSPF and EIGRP routing protocols for greener internetworking, Published in: 2013 International Conference on Green High Performance Computing(ICGHPC), 14-15 March 2013, Nagercoil, India https://doi.org/10.1109/ICGHPC.2013.6533929

[12] Z. Xiyang and C. Chuanqing, "Research on VLAN Technology in L3 Switch," 2009 Third International Symposium on Intelligent Information Technology Application, Shanghai, pp. 722-725. doi: 10.1109/IITA.2009.498, 2009

[13] Xiaoying Wang, Hai Zhao, Mo Guan, Chengguang Guo and Jiyong Wang, "Research and implementation of VLAN based on service," GLOBECOM '03. IEEE Global Telecommunications Conference (IEEE Cat. No.03CH37489), San Francisco, CA, pp. 2932-2936 vol.5, 2003.
[14] I. Fiţigău and G. Toderean, "Network performance evaluation for RIP, OSPF and EIGRP routing protocols", Proceedings of the International Conference on ELECTRONICS, COMPUTERS and ARTIFICIAL INTELLIGENCE - ECAI, Pitesti, 2013, pp. 1-4, 2013. https://doi.org/10.1109/ECAI.2013.6636217

[15] Anuka Pradhan, Biswaraj Sen "A brief study on Contention Based Multi-Channel MAC Protocol for MANETs", International Journal of Emerging Trends in Engineering Research (IJETER), Vol 6, No 12, pp 74-78, Dec 2018. https://doi.org/10.30534/ijeter/2018/016122018

[16] Kyeongjoo Kim, Jihyun Song, Minsoo Lee " Real-time Streaming Data Analysis using Spark", International Journal of Emerging Trends in Engineering Research (IJETER), Vol 6, No 1, pp 1-5, Jan 2018. https://doi.org/10.30534/ijeter/2018/01612018

[17] Saleem Akram P., Ramana T.V, "Stacked electromagnetic band gap ground optimization for low profile patch antenna design", International Journal of Engineering and Advanced Technology, ISSN:22498958, Vol No:8, Issue No:3, 2019, pp: 146 154.

[18] P.Saleem Akram, Dr.T.Venkata Ramana "Mobile Aided Improved Trilateral Localization by adopting random way point pattern". ARPN Journal of Engineering and Applied sciences. Vol 12, No 21, Nov 2017

[19] Rao, K. R., Kumar, T. R., \& Venkatnaryana, C. (2016). "Selection of anchor nodes in time of arrival for localization in wireless sensor networks" doi:10.1007/978-81-322-2671-0_5

[20] Sahiti, V., Raghava Rao, K., \& Mohan Rao, K. R. R. (2016). "Hashing technique data optimization for low power consumption in wireless sensor network. Indian Journal of Science and Technology", 9(17) doi:10.17485/ijst/2016/v9i17/93101

[21] Abdul A.M., Krishna B.M., Murthy K.S.N., Khan H., Yaswanth M., Meghana G., Madhumati G.L., "IOT based home automation using FPGA", 2016, Journal of Engineering and Applied Sciences, Vol: 11, Issue: 9, pp: 1931 - 1937, ISSN 1816949X

[22] Narayana M.V., Dusarlapudi K., Uday Kiran K., Sakthi Kumar B., "IoT based real time neonate monitoring system using arduino",2017 Journal of Advanced Research in Dynamical and Control Systems,Vol:9, issue:Special issue 14,pp: 1764-1772,DOI: ,ISSN: 1943023X

[23] Gadde S.S., Ganta R.K.S., Gopala Gupta A.S.A.L.G., Raghava Rao K., Mohan Rao K.R.R. ., "Securing Internet of Things(IoT) using honeypots" , 2018, Microsystem Technologies ,Vol: 24 ,Issue: 3 ,pp: 1609 to:: 1614 ,DOI: 10.1007/s00542-017-3563-x ,ISSN: 9467076

[24] Ravikanth, B., Akram, P. S., Ashlesha, V., \& Ramana, T. V. (2017). "Tuning operating frequency of antenna by using metasurfaces. Paper presented at the International Conference on Signal Processing, Communication, Power and Embedded System", SCOPES $2016 \quad$ - Proceedings, 20642068.doi:10.1109/SCOPUS.2016.7955

[25] Gopi Krishna P., Srinivasa Ravi K., Hareesh P., Ajay Kumar D., Sudhakar H. ., "Implementation of bidirectional blue-fi gateway in IoT environment", 
2018, International Journal of Engineering and Technology(UAE) ,Vol: 7 ,Issue: ,pp: 733 to:: 738 , ISSN: $2227524 \mathrm{X}$

[26] Saleem Akram, P., \& Ramana, T. V. (2019). “Two dimensional beam steering using active progressive stacked electromagnetic band gap ground for wireless sensor network applications". Journal of Computational and Theoretical Nanoscience, 16(5-6), 2468-2478. doi: $10.1166 /$ jctn.2019.7918

[27] Muzammil Parvez M., Shanmugam J., Mohan Rao K.R.R., Lakshmana C., Shameem S. ., "Alive node and network lifetime analysis of DEEC protocol and EDDEEC protocol" , 2018, International Journal of Engineering and Technology(UAE), Vol: 7 ,Issue: ,pp: 661 to:: 664 ,,ISSN: $2227524 \mathrm{X}$

[28] Pavithra T., Sastry J.K.R. ., "Strategies to handle heterogeneity prevalent within an IOT based network" , 2018, International Journal of Engineering and Technology(UAE) ,Vol: 7 ,Issue: 2 ,pp: 203 to:: 208 DOI: 10.14419/ijet.v7i2.7.10293 ,ISSN: 2227524X

[29] Devi Susmitha, N., Sowmya, S., Akram, P. S., \& Ramana, T. V. (2017). "Tuning of L-C meta-material structure for antenna applications" . Paper presented at the International Conference on Signal Processing, Communication, Power and Embedded System, SCOPES 2016 - $\quad$ Proceedings, 1845-1850. doi:10.1109/SCOPES.2016.7955764

[30] Poonam Jain S., Pooja S., Sripath Roy K., Abhilash K., Arvind B.V. ., "Implementation of asymmetric processing on multi core processors to implement IOT applications on GNU/Linux framework" , 2018, International Journal of Engineering and Technology(UAE) ,Vol: 7 ,Issue: 1.1 ,pp: 494 to:: 499 ISSN: 2227524X

[31] Rambabu K., Venkatram N. ., "Traffic flow features as metrics (TFFM): Detection of application layer level DDOS attack scope of IOT traffic flows" , 2018, International Journal of Engineering and Technology(UAE) ,Vol: 7 ,Issue: 1.1 ,pp: 554 to:: 559 ISSN: 2227524X

[32] Bhatt, P., Akram, P. S., \& Ramana, T. V. (2015). “A novel on smart antennas to improve performance in wireless communications". Paper presented at the International Conference on Signal Processing and Communication Engineering Systems - Proceedings of SPACES 2015, in Association with IEEE, 187-190. doi:10.1109/SPACES.2015.7058245

[33] Saleem Akram, P., \& Venkata Ramana, T. (2019). “A novel approach of microstrip fed planar monopole antenna for wsn applications at 2.4ghz ism band". International Journal of Scientific and Technology Research, 8(8), 665-669. 